Olívia M.G. CUnha

\title{
TRAVEL, ETHNOGRAPHY, AND NATION IN THE WRITINGS OF RÓMULO LACHATAÑÉRÉ AND ARTHUR RAMOS
}

In 1928-1929 the Brazilian writer Mário de Andrade began publishing in a local newspaper the material he had collected during his travels to the interior of Brazil. ${ }^{1}$ The journal entries, personal itineraries, essays, poetry fragments, and photographs he had amassed over two long journeys through the northern and northeast regions composed a unique ethnography, which Andrade entitled $O$ turista aprendiz (1976, The apprentice tourist). The idea of the scholar abandoning the "center" and, therefore, displacing urban culture and written language, a notion inherent in his own experience, made him view travel as an experience of interpretation rather than merely observation. Through what was an attempt at producing an ethnography, Andrade not only generated information, but created a unique encounter inspired by the idea of apprenticeship. Instead of conceiving of himself as an ethnographer, Andrade preferred to think of himself as a special kind of tourist, there not only to observe, but also to learn.

The intriguing connections between anthropology, modernism, and nationalism in the work of Mário de Andrade invite comparisons with other Latin American texts from the same period (Guicharnaud-Tollis 1982, Kutzinski 1993, Masiello 1993). However, in this essay, the modality of travel described in $O$ turista aprendiz will be used not as a paradigm, but as an inspiring starting point to explore an issue which has been examined

1. The first version of this essay was presented at the Center for Latin American Studies Seminar at the University of Michigan, on March 27, 2000. I owe many thanks to Sueann Caulfield, Julie Skurski, and Fernando Coronil for their stimulating comments. Different phases of the research and writing received generous support from Verena Stolcke, Sally and Richard Price, Rosemarijn Hoefte, and the three anonymous reviewers of $N W I G$ who helped me to clarify both text and ideas. I am thankful to the collegiality of Diana Lachatañeré and Kevin Yelvington who shared their own research material with me. Hilary Burger, Jessica Callaway, and Amy Chazkel revised different versions of this essay. I thank DRCLAS at Harvard University and CNPq for the research support.

New West Indian Guide / Nieuwe West-Indische Gids vol. 81 no. 3 \& 4 (2007):219-257 
in the anthropological literature from different perspectives: the place(s) designated local, peripheral, native, or national by anthropological interpretations in the constitution of different areas or fields of the discipline. ${ }^{2}$

The image of an "apprentice anthropologist" brings to mind the work of two very different Latin American intellectuals, both of whom were living in the United States in the early 1940s, Rómulo Lachatañéré (1909-1951) and Arthur Ramos (1903-1949). Besides being travelers, both authors had been involved in transnational arrangements and politics of institutional cooperation aimed at establishing the means for debate, research, and teaching of Afro-American studies in institutions in the United States and Latin America. These academic and cultural policies involved diverse situations and intellectual positioning regarding political cooperation, activism against racism, and other experiences that combined exile and professional training. A careful examination of these positions allows us alternative insights into the trajectories of these authors in the United States, and the images they produced on the place of "race" in national representations. Each one permits us to discover a different history of the field they helped to create in the discipline, allowing us to understand the national intellectual tradition in which they were formed and ex- or included, and, mainly, the place of travel as an experience of displacement and reflection through which the exercise of comparison was possible. In the following, I approach two professional trajectories directly linked to experiences of travel and displacement as an object of analysis so as to be able to reflect on these forms of inscription and their implications in possible readings on the production of histories of the discipline, the birth of so-called Afro-American Studies, and the transnational dialogues that allowed for the production of knowledge, forms of subjectification, and images of nation that populate the intellectual debate from 1930 to the 1950s (Price \& Price 2003, Yelvington 2006).

\section{TRAVELS AND TRAVELERS}

In the archive of Arthur Ramos, maintained by the National Library in Rio de Janeiro, the record of Ramos's experience in the United States is presented as it relates to his contributions to the development of anthropology in Brazil. Postcards, photographs, letters, syllabi, posters advertising lectures, train tickets, abbreviated notes and a series of short essays published in Brazilian newspapers document Ramos's stay and travels in the United States between 1940 and 1941, during which time he lectured at Louisiana State University. Lachatañéré's papers have not been brought together in a single archive and

2. Asad 1973, Fahim 1982, Cardoso de Oliveira 1988, Fardon 1990, Narayan 1993, Thomas 1994, Peirano 1998, Gupta \& Ferguson 1997. 
remain dispersed among several different national and ethnographic archives. While Ramos came as part of a "cultural exchange," Lachatañéré left Cuba in 1939 shortly after having been arrested because of his involvement with the Cuban Communist Party. From Baton Rouge and the streets of Harlem they reflected on Brazil, Cuba, their experiences, and their places in the configuration of a "field" and their role in its development. The differences between Ramos and Lachatañéré are remarkable when we consider their professional status and public intellectual recognition - questions that go beyond the scope of this text - not to mention their particular approaches to shared topics of interest. Beyond the "places" occupied by each in national histories of the discipline, there are differences in regard to the volume of their respective "intellectual productions." Ramos produced an enormous quantity of books and articles during his career as a psychiatrist and anthropologist, while Lachatañéré had set out to begin formal training in anthropology when he died suddenly in a plane accident. In contrast to Lachatañéré's condition as an exile in the United States, where he went in 1939 to escape political persecution in Cuba, Ramos was in the country because of the "Good Neighbor" policy involving cultural, economic, and political ties between Latin America and the United States (Espinosa 1976, Pike 1995). It was in these terms, at least, that his visits to different North American universities were understood by those who sponsored his lectures and meetings. ${ }^{3}$ Nonetheless Ramos's and Lachatañéré's writings during and after their stays in the United States between 1939 and 1951 reveal identical approaches to the tasks involved in defining, describing, and interpreting the relation between nation and race, respectively, in Brazil and Cuba. Although they shared a mixture of repulsion and attraction to the troubled racial politics and images of the United States, Lachatañéré's and Ramos's writings reveal dissimilar intellectual and political perspectives.

As many studies have shown, experiences of displacement associated with specific forms of production of knowledge are also directly linked to other forms of colonial and imperial expansion. ${ }^{4}$ Since the 1960 s, many authors

3. As mentioned by Elsie Clews Parsons in a letter to her friend and protégé Melville Herskovits, Ramos and the Peruvian folklorist Fernando Romero were "sent" to her by the U.S. Department of State (Elsie Clews Parsons, March 20, 1941, Melville Herskovits Papers, Box 18, Northwestern University Archives, [hereafter MHP/NWUA]) in Evanston, Illinois. In this same year, the Brazilian Dante de Laytano, a specialist in folklore and the history of southern Brazil, traveled to Washington and later visited Fisk University under the auspices of the Department of State (letter, M. Herskovits to Charles S. Johnson, September 25, 1942, Box 25, MHP/NWUA). Elsewhere I have described Ramos's uses of this trip after his return to Brazil in 1941 (Cunha 2004). For a list of Latin American and North American scholars sponsored by the cultural exchange policy between 1936 and 1948 see Espinosa 1976.

4. Pratt 1986, 1992, Clifford 1988, 1989, 1992, 1997a, 1997b, Scott 1989, 1991, Marcus 1991, Hulme \& Youngs 2002. 
have been pointing to the politics of production of anthropological knowledge, immersed in a tangled field of relations of power inside and outside academic institutions. ${ }^{5}$ The advent of "area studies" in the post-World War II period, for instance, subjected to critical analysis through connections to other forms of political intervention linked to the production of knowledge, is an important example in which travel, transnational intellectual dialogues, and politics of exchange are intimately linked. With regard to Latin America and the Caribbean, the rare existing historical analyses are partial descriptions that overlook to some extent the historical vicissitudes and political implications of this construction (Mintz 1964, 1977, 1998, Slocum 2003).

In most cases, intellectual and institutional expansion in diverse fields is described as the logical outcome of a process of intervention within the political context of the discipline in the United States. A large tree with strong and long branches could be a kind of metaphor and model for the representation of the process of reproduction of the discipline, as well as its respective practices and relations in "center" and "periphery" settings. The movement of reproduction, appropriation, criticism, and contestation of ideas, positioning, and canons seems consistently to follow a north-south orientation. However, it is possible, at least, to imagine another alternative historical narrative that instead of challenging and shifting these polarized efforts, stresses their provisional and transnational dimensions (Mintz 1977, 1998, Trouillot 1992, 1998, Yelvington 2006). Besides the political implications of the conditions that permitted the expansion of "specialized travel" and the kind of representations of "others" produced by "metropolitan observers" in postcolonial areas, little attention has been paid to more recent forms of travel developed in this period in the opposite direction (Narayan 1993, Peirano 1998, Di Leonardo 2000). That is, travelers who crossed the boundaries of settings canonically established as sources of anthropological knowledge, on the way to other "settings" supposedly conceived of as places for analysis, theorization, and reflection about data gathered elsewhere.

Examining the sources related to the birth of Afro-American studies, including publications, minutes of meetings, letters, and dissertations written by its most influential figures in the mid-1930s and 1940s, I realized that the experience of travel on the part of Latin American scholars, especially to the United States, played a significant role in the elaboration of interpretations of the interplay between race and nation in Latin America. The travels in question were not necessarily conceived of as "ethnographic trips" or "field trips" but understood as professional training experiences. ${ }^{6}$ After 1936, "cultural

5. Wolf 1974, Mead 1979, Stocking 1992, Borneman 1995, Goldman \& Neiburg 1998.

6. Editorial limitations do not allow me to detail the institutional policies initiated in this period, nor their impact in Latin American intellectual settings. Although in this essay I have relied on material related to Ramos's and Lachatanéré's travels in the United States, 
exchange" involving the United States and selected Latin American countries had become standard practice through different, although related, policies instituted by the U.S. Department of State and various North American educational and research institutions. ${ }^{7}$ The expression "cultural exchange" is mentioned not only in the official minutes of meetings about American economic and foreign policy regarding what were then called the Hispanic Republics, but also in academic and intellectual circles in both the United States and Latin America. ${ }^{8}$ What inspired me to explore these policies further is the way in which different experiences of travel conceived of as cultural exchange to implement official political and educational agendas, as well as travel as exile and critical positioning on national politics of race, mediated and informed a complex transnational dialogue between scholars and students in the field of Afro-American Studies in Latin America.

It is important to emphasize that Ramos and Lachatañéré did not follow the same agendas and travel destinations prescribed by these policies of exchange. Whereas they had gone to the United States with different motives and objectives, they moved in similar intellectual spaces and networks, drew

my understanding was made possible through contact with other archives and collections of North American and Latin American contemporary authors who engaged in field research who were involved in cultural exchange programs or both. Among others, I carried out research in the Arthur Ramos Collection (Biblioteca Nacional do Rio de Janeiro), Melville Herskovits Papers and Melville and Jean Herskovits Papers (respectively, Northwestern University and Schomburg Center for Black Culture, New York), Julius Rosenwald Fund (Fisk University, Nashville, Tennessee), Fernando Ortiz Collections (Instituto de Literatura y Linguística and Biblioteca Nacional José Martí, both in Havana). Important parts of Lachatañéré's private documents were kindly made available by his daughter, Diana Lachatañéré, curator of the Rare Books and Manuscripts Division at the Schomburg Center for Black Culture. She has been collecting her father's professional documents and has done research on institutions with which Lachatañéré made contacts during his stay in the United States, namely, the Julius Rosenwald Fund and Columbia University. References to these materials will appear here as "courtesy of Diana Lachatañéré."

7. See especially the following issues of the Department of State Bulletin: "Exchange of Professors and Students between the United States and the other American Republics," 1939 (13:289-91); "Conference on Inter-American Relations in the Field of Education," 1939 (19:464-5:146); "Inter-American Professor Exchange," 1940 (41:357-62); "Exchange Professors and Students," 1940 (61:149). See "Travel Grants to Professors and Students," 1940 (67:282).

8. An exception to the trend among U.S. researchers of travel to different Latin American countries, Brazilian anthropologist Octávio da Costa Eduardo was a student of Melville Herskovits between 1941-1943 on a U.S. Department of State fellowship, and a Rockefeller fellowship, which was granted in 1942 for the purpose of gathering "observations about the Negro situation in the South and other areas" ([letter] Octávio da Costa Eduardo to Brazilian consulate in Chicago, Evanston, Illinois, April 26, 1943, Octávio da Costa Eduardo Papers, Box 1, Folder 1, Northwestern University Archive [hereafter OCEP/ NWUA]). 
similar expectations and interests on the part of their American colleagues and used information and knowledge gathered during their travels as central elements of a comparative discourse. At the same time, the texts that narrate or refer to these experiences do not constitute travel writings as a narrative genre or ethnographies, if they are interpreted from an academic perspective. What Ramos and Lachatañéré had in common in the writings produced during or after traveling to the United States was not related to their specific travel experiences, but to the merging of ethnographic and travelogue styles in political exile, cultural exchange policies, and personal projects. In this sense, they do not reduce these texts to simple events in their different professional trajectories but to a body of knowledge that gives birth specifically to forms of intellectual dialogue and positioning.

\author{
"THROUGH THE BACKYARD OF AMERICA": \\ A BRAZILIAN TRAVELER IN BATON ROUGE
}

\begin{abstract}
It is not the poetry of the river that waits for us: it is the crude and monumental symphony of oil which penetrates the senses, when we enter through the backyard of America (Ramos 1940a:49).
\end{abstract}

Among the various remnants, photographs, and texts that document Arthur Ramos's travel through different cities and university campuses in the United States, certain items caught my attention. Out of drafts and copies of letters, I came across a collection of notes entitled "Brazil Misunderstood," probably written on board the ship that brought Ramos and his wife back to Rio. These consisted of a short list of carefully numbered points that exposed foreign ignorance of basic information on South America. On a tiny piece of paper there were statements such as "Brazilians speak Spanish," "The capital of Brazil is Buenos Aires," and "The Indian population can be seen in Brazilian cities." It is not difficult to imagine Ramos's frustration. He often described his role in the United States as that of a translator, charged with teaching "Brazil for beginners." From the time he left Brazil in the autumn of 1940, he seemed to consider his travel a kind of missionary practice that combined nationalist sympathies and professional commitments. In the journal Diretrizes, he published a column in which he presented weekly renderings of his experience in the United States. Entitled "Movimento cultural" (Cultural movement), it was intended to be "a special correspondence on cultural issues and everyday aspects of North American life" rather than ethnography. While not claiming to be authoritative, his impressions served

9. See, for example, Ramos 1939 and 1941b. 
to draw attention among a wider audience to Ramos's reputation and unusual sensibility during his "travel of studies." He wrote his first descriptions of what he called the "antechamber of America" on the basis of observations about the way North American passengers on the Delta Line regarded him. A university professor, and not an exotic product of the tropics, Ramos sought to present and explain Brazilians and "Brazilian Culture" to a select audience. In his first writings, apparently written on board the ship, high-school teachers, college students, middle-class families, and a missionary who had been "among the Maoris," were some of the diverse individuals he mingled with the memories of an already homesick traveler. ${ }^{10}$

Arthur Ramos was, however, more interested in other things. He often told readers of his column that, in addition to teaching courses on "Race and Culture in Brazil," he intended to conduct research on the culture and behavior of the Black population in the Deep South to compare his findings with his Brazilian data. This interest deserves greater consideration in light of his prior experiences as a researcher in the then emerging field of Afro-Brazilian Studies during the 1930 s.

As the son of a prestigious physician and a traditional family from Pilar (a small city in the state of Alagoas) Ramos shared with his generation and its professors an engaged view of the role of medicine. ${ }^{11}$ Medicine was seen as part of a wider curative and redemptive project of social transformation rather than as exclusively limited to clinical therapy. Moving from catastrophic to more optimistic interpretations of the effects of race and social mixture in Brazil, Ramos's intellectual generation envisioned multiple mechanisms to correct the nation's ills: poverty, illiteracy, illness, backwardness, and, for some authors, signs of "degeneracy." Eugenic and nationalist projects endorsed most of the corrective prescriptions that a number of authors had produced to heal the nation. Curiously, instead of being diametrically opposed, some of them were complementary. Interchanging categories such as "race" and "individual" - often associated with notions of a racialized national image and nationalized

10. Ramos 1940b. In his notes his encounter with this ethnologist-missionary would have occurred on September 12, 1940. See also Ramos 1940a:10-12.

11. Although Ramos's influence was decisive for the institutionalization of anthropology in Brazil and the choice, in the early 1950s, of Brazil as a laboratory for research on race relations, there are few works dedicated to his varied political and intellectual participation in the discipline. For forensic influences in his work, and later, his affinities with acculturation studies, Ramos's ideas and works were considered outside the discipline to be something less defined or very close to a folklorist tradition, or, at least, classified as a kind of prehistory of anthropology in Brazil. This view is directly related to the criticism of acculturation studies in the Brazilian anthropological literature of the 1950s and 1960s. On different aspects of Ramos's career and works, see Fernandes et al. 1950, de Souza Carneiro 1951, Diaz Duarte 1997, Correa 1998, Stolcke 1998, Chor Maio 1998, and Cunha 1999. For a biographical account see Barros 2005. 
"racial identity" (as, for instance, "Brazilian race" and "Colored Brazilians") - they focused on national illness and disorder through metaphors inspired by medical and biological terminology. As a body, the nation deserved not only a panacea, but also interpretive tools that would help its interpreters, who were frequently upper class, conservative, and state representatives of the intellectual elite, to invest in unique narratives of brasilidade: Brazilians and Brazil's past and fate. This tendency followed diverse intellectual orientations and constituted a complex territory of ideas involving social movements, artistic engagement, aesthetic desires, and political commitments related to the process of institutionalization of the social sciences in Brazil. ${ }^{12}$

Scientific approaches and nationalism were linked through local and national perspectives. A prestigious group of intellectuals, of Ramos's generation, who had graduated from medical and law schools, was committed to both regional and national interpretations of a subject Nina Rodrigues had hyphenated and studied from a scientific perspective in the late nineteenth century, the "Afro-Brazilian element." When the young Arthur Ramos left Pilar by 1922 to study at the prestigious Faculty of Medicine of Bahia in Salvador, he found an exciting setting for research and studies devoted to public health, tropical disease, and forensic medicine strongly inspired by Cesare Lombroso and ideas of Italian criminology. During his period of residence in a psychiatric hospital in Salvador, Ramos came into contact with new therapies and literature on mental illness that related some of its manifestations to "primitive people and cultures." He was also called on to deliver diagnoses of mental disorders associated with Afro-religious practices, whose sufferers were at that time persecuted by the police and local authorities. In his doctoral thesis and first book Primitivo e loucura (1926, Primitiveness and madness), and later, his dissertation prepared for tenure, Sordidness among Madmen, (1928, A sordície nos alienados), Ramos used "cases" he collected in both the hospital and the penitentiary as primary data for his first works on ethnology and psychiatry $(1928,1931,1932,1933 a, 1933 b, 1934,1935$, 1937). Inspired by the ideas of Nina Rodrigues and theories of Lévy-Bruhl on the mental incapacity of "primitive cultures," he viewed delinquency and madness among Blacks as unconscious manifestations that deserved treatment rather than punishment. ${ }^{13}$ His 1928 work was in part the result of an

12. Lamarckian approaches were extremely popular among Brazilian authors during this period. They are the core of "Whitening" ideas, but can also be found in the theories of its well-known critics, such as Gilberto Freyre. See Stocking, Jr. 1968, Stepan 1991, and Araújo 1994. On body and degeneration metaphors see Lenharo 1986, Ventura 1991, Borges 1993, Needell 1995, and Cunha 1999, 2002.

13. He was an ardent supporter of the adoption of medical, hygienic, and psychological techniques in the study of juvenile delinquency, crime, and problems related to the education of children (Dias Duarte 2000). 
assignment from the chief of police, Bernardino Madureira de Pinho, to study the installation of an insane asylum in Salvador. It was also by this time that he entered into contact with similar approaches used by Fernando Ortiz in Cuba. Among his notes and reviews of criminology and psychiatry periodicals, probably written in the late 1920 s, I found penciled comments on a series of cards which suggest that he had discovered some convergence between data collected by Ortiz in Havana and those documented by Nina Rodrigues more than twenty years earlier. Reading Ortiz's depictions of "the superstition of criminals" among Afro-Cubans in Havana, Ramos noticed the combination of different religious traditions in contact in a setting of marginalization. The combination of African and Catholic saints in Cuba and Brazil formed the basis for what Nina Rodrigues called "fetishistic practices" among the Black population. Ramos at that time called the combination of practices from diverse religious origins "a phenomenon of assimilation." Understanding it in this way did not allow him to imagine any further conceptual implications of its use, and he would later refer to it with the term "syncretism" (Herskovits 1958:xxii, 249, 250). Indeed, in the earliest of his writings, Ramos recognized Nina Rodrigues's authority regarding the prominence of Yoruba religious practices among Brazilian Negroes:

$\mathrm{He}[\mathrm{Ortiz}]$ reveals (exactly as Nina did in Bahia) Black and slave fetishist remnants in Cuba ... African fetishism was maintained in Cuba not only due to the natural inferior state of the Black race - but also to different psychic stratifications of imported masses of Whites, whose proximity to the African level of psyche, has facilitated the communion of ideas and racial prejudice. ${ }^{14}$

Although his interests and professional activities made him known to an influential generation of intellectuals devoted to the uses of scientific tools in social reform projects, Ramos's intellectual trajectory wavered between two apparently contradictory tendencies. On the one hand he maintained friendships and built ties with a group of Bahian intellectuals, adherents of what they called the Nina Rodrigues School who took a characteristically scientific approach to treating the "Negro problem." On the other hand, his transition from forensic approaches to a focus on psychoanalysis drew him into the terrain of ethnology. It was through a psychological perspective that Ramos transformed the racial determinism of Nina Rodrigues's ideas into an ethnological problem. More than relying on positivist criminological literature as Rodrigues and many of his disciples had, Ramos chose to focus on mental illness, criminality, and the so-called pathological behaviors attributed to "backwards and primitive races" using Freud and Lévy-Bruhl's ideas.

14. Arthur Ramos's notes, [1926-28], Folder 38, 1, BN/CAR. 
Starting in 1928, when Ramos began to work as a psychiatrist in the São João de Deus hospital in Salvador, he had demonstrated talent and skill in combining medical and forensic practices with a more social-sciences-oriented approach to "primitive cultures" and folklore. ${ }^{15}$ After having moved to Rio de Janeiro in 1933 to work at an institute of psychological and educational research, Ramos was no longer exclusively a physician and psychiatrist devoted to issues of mental illness. Besides Freud and Lévy-Bruhl, he had been timidly incorporating other literature into his eugenic and pathological view of race issues in Brazil. This move had to do with his interest in studying Afro-Brazilian folklore and religious practices. ${ }^{16}$

To understand the "Negro mentality" Ramos became an avid reader of the history of slavery in Brazil and the New World, Africanist ethnology and history, and religion. His first book entirely devoted to "negro religion and folklore," O negro brasileiro (1934), is a collection of essays in which data on slavery and the history of the Atlantic slave trade combined with readings on African cultures form the background for a wider understanding of the history and culture of the Brazilian Negro. Contrary to Gilberto Freyre who a year before had published Casa grande \& senzala (The Master and the Slaves; see Freyre 1946) as a sociological history of Brazilian society, Ramos's first writings on what was called the "Negro problem" were the result of a distinct and intense political engagement. Combining his previous experiences as a physician and psychiatrist in Salvador and Rio, short fieldwork experiences among practitioners of Afro-Brazilian cults in some northeastern cities, contact and correspondence with Afro-Brazilian movements in São Paulo, and wider literature on slavery and religion, Ramos not only reoriented his initial perspective but also used this knowledge to support public and political battles against racial determinism. Between 1934 and 1938 he advocated and participated in public debates about murders involving accusations of witchcraft, religious and messianic movements, and banditry in northeastern Brazil, stressing their cultural and social rather than their "racial" causes and implications. In a period marked by strong intellectual nationalist-oriented activism, Ramos was often called upon to advocate his ideas against racial determinism. In 1935 he championed a manifesto against racism and later promoted it in many public debates on the criminality of the poor, illiterate,

15. Ramos assumed explicitly these interests and his contacts with "race problems" through forensic practices (Ramos 1940c:38).

16. It was through Ramos's commitment to highlighting the cultural orientation of practices usually observed through a pathological perspective that his authority as an anthropologist specialized in "Negro issues" emerged. Moreover, the influence, prestige, and encouragement of Afrânio Peixoto, a former student and most prominent follower of Nina Rodrigues, were decisive in recognizing Ramos's leadership in the "Nina Rodrigues School." On the Nina Rodrigues School see Correa 1998. 
and racially mixed population from the backwards northeast, and in marking the official celebration of the fiftieth anniversary of abolition (Stolcke 1998, Cunha 1999).

Ramos assumed without hesitation that his intellectual trajectory had suffered shifts. In his first letter to Roger Bastide in 1938, he introduced himself as someone who came into contact with Bahian Blacks "and other popular groups" through his profession as a clinical and forensic physician: "Initially I became interested in studying psycho-physiological manifestations in certain Black religious phenomena, mainly, the so called estado de santo [state of saint]." 17 In a way, anthropology in Ramos's work was seen as a theoretical and methodological tool, as well as a kind of modern language to deal with culture (Wagner 1981). Between 1932 and 1937 he published three books, and also articles, which together consecrated him fully as a Brazilian anthropologist (Stolcke 1998, Barros 2005).

Within this tradition and nationalist commitment we can situate Ramos's view and interpretation of anthropology and its derived practice, fieldwork. Medical reports and stories collected by his relatives and friends in Alagoas, Bahia, and Rio de Janeiro have figured as the main "sources" of his well-received books $O$ negro brasileiro (1934) and O folk-lore negro do Brasil (1935). In many cases, access to practitioners of sects (seitas) was facilitated by the hierarchical position his informants maintained with their domestic servants, employees, and their respective relatives and friends. In Pilar, where he returned once in 1932 following his departure for Salvador, Ramos established a network of informants with the help of relatives. In Salvador, his friendship with the person whom he called his student, Édison Carneiro, brought him material and symbolic benefits. Carneiro sent considerable information on Candomblé and other Afro-Brazilian cults. Although the extent and nature of the practice of ethnographical data was not well known, as the Brazilian anthropologist perhaps most well known during the 1940s, Ramos, suffered accusations of a lack of training in anthropology and the excessive influence of Nina Rodrigues in his work. In fact, what really mattered for him was finding, discovering, and collecting "facts," the main subject of his preoccupations. "Their systematization," he pointed out, "will come naturally later": "by asking the 'how' of these facts, we will be following the historical-cultural 'method,' by asking its 'why,' we will be engaging in psychoanalysis" (Ramos 1935:11-12). ${ }^{18}$

To his prior identity of collector, Ramos added that of traveler. The shifts that occurred in Ramos's work are also related to his experience in the United

17. Arthur Ramos, Rio de Janeiro, 1/8/1938, BN/CAR.

18. In this book (1935), Ramos thanked his "informants," and "social psychology and Brazil's history professors." I discuss some of implications of Ramos's ethnographic data elsewhere (Cunha 2004). 
States. However, they have more to do with his engagement with a wider intellectual context and conversation about the role of anthropology in wartime. Whether observing him as a traveler with a (nationalist) project, or approaching his travel as a project reconfigured through the experience of a specialized tourist, we can consider a number of passages from Ramos's sojourn in the United States in association with the tokens he preserved in his archives. Among them are his speeches, lectures, and presentations in round-tables at universities, professional associations, and discussion groups on problems of war.

Ramos's contact with North American agencies and scholars began around 1938, and involved mutual interests. It was Richard Pattee, a professor of Latin American history at the University of Puerto Rico who, according to Espinosa (1976:92), was "an expert on inter-American cultural history" recruited by the Division of American Republics (Department of State) to improve the contacts between North American and Latin American scholars and educational institutions. Pattee first made possible the communication between intellectuals such as Ramos, Melville Herskovits, Fernando Ortiz, Jean Price-Mars, and others. ${ }^{19}$ Through Pattee's mediation and intervention, some of these scholars initiated a prolific correspondence not only about their research interests and plans but also about the possibility of benefiting from these cultural exchange programs. These interventions aimed to implement good nationhood politics through cultural exchange programs but, mainly, to disseminate the achievements of U.S. higher education institutions in Latin America. As a Rockefeller Foundation representative writes in a letter to Herskovits:

\begin{abstract}
A small number of the best men would be more effective in transmitting to Latin American Scholars and institutions a knowledge of the Social Science methods developed in our own country; such men would be able to size up the research opportunities available to younger American scholars in these countries; and through a detailed knowledge of the problems and of the personnel of the various Latin American countries they would be in a position to furnish adequate advice to American foundations and other institutions for the training of Latin American personnel in the social sciences. ${ }^{20}$
\end{abstract}

As Ramos justified to Herskovits in one of the first letters exchanged by both in 1938, his "most ardent desire was to bring together as much as pos-

19. However, besides Pattee's trip and personal contacts with Latin American and North American intellectuals, a set of ambitious programs of cooperation was already being implemented by private U.S. educational institutions and Latin American governments and scholars. The role of the Division of Cultural Relations at the Department of State as a "coordination" of these programs was to select and evaluate scholars nominated as potential fellowship recipients, and, organize the Latin American visitors' trips within the United States.

20. Philip E. Mosely, August 4, 1941, Box 20, NWUA/MHP. 
sible Brazil to North America." ${ }^{21}$ However, Ramos's first applications were neglected by the Rockefeller and Guggenheim Foundations owing to the Brazilian stance in the war. ${ }^{22}$ Only in 1940, through the intervention and notoriety of Herskovits, Lewis Hanke, and Richard Pattee did he receive a Guggenheim Fellowship to extend his studies at Northwestern University following his stay as a lecturer at Louisiana State University. ${ }^{23}$ However, wartime somehow changed Ramos's interest in a stay at a U.S. university. During his trip, Ramos was invited by many scholars and institutions to speak about Brazil, and mainly about its racial ideology during war times, rather than the research he was supposedly doing as an anthropologist. His position on race relations in Brazil attracted the interest of diverse intellectuals engaged in the politics of race within and outside academic arenas (Ramos 1941c, 1943a, 1949).

In their interest in placing war problems on the social science agenda for inter-American cooperation, Melville Herskovits and Charles A. Thompson, the chief of the Division of Cultural Relations at the State Department, included both Arthur Ramos and Gilberto Freyre as Brazilian representatives at the seminar on "Racial Minorities in the Present International Crisis" held at Stanford in 1941. The organizers anticipated that Ramos would play an important role in this meeting. They expected that Ramos would combine his impressions on race relations in Brazil and the future of democracy in the Americas. In a letter of invitation, they recommended the overarching theme that would orient his paper. "A brief but comprehensive statement describing the present position of the Negro in Brazil as a minority racial group," with reference to the importance of strengthening political alliances between Brazil and the United States. They asked that he include explanations about "the extent to which Hitler's victory in Europe might have on the present position of the Negro in Brazil," and an indication of what the "position of the Negro in Brazil would be, could be, and should be if Britain or the United States wins and democracy is saved for the world." ${ }^{24}$ Ramos added

\section{Arthur Ramos, May 30, 1938, CAR/BN.}

22. The official position of the government of Getúlio Vargas regarding Axis influence was deemed ambiguous by the U.S. government agencies; it was also taken into consideration by North American intellectuals, institutions, and foundations in the selection and sponsorship of scholars and students from Brazil.

23. Although connected to Herskovits and interested in carrying out fieldwork in the U.S. South, Ramos went to the U.S. by invitation of the urban sociologist T. Lynn Smith who went to Federal University of Rio de Janeiro in 1946 and wrote extensively on agrarian issues on Brazil.

24. Charles A. Thompson, March 5, 1941, Box 19, Folder 14, NWUA/MHP. In the first American Anthropological Association meeting that devoted a special session to a discussion of the South American ethnic situation, Ramos's presence as a Latin American scholar held powerful and authoritative importance. Melville Herskovits, particularly 
to his very optimistic views of the situation of the Afro-Brazilian population the idea that Brazil's role in the debate about the war would not only influence but would be used as a model for democratic society. As he stated in his depictions of Brazilians' views on race:

\begin{abstract}
Negroes and Mulattos are integral elements of the national life; their opportunities are the same as the other racial groups in the participation in social and cultural activities. This tradition in the treatment of races is a matter of pride in Brazil. Negroes and Mulattos as well have the same opportunities and participate in all aspects of Brazilian life ... the discussion of superiority or inferiority of races has never been raised in Brazil. There is no "master race" in Portuguese America. I do not think, therefore, that the situation of the Brazilian Negro is connected with the destiny of the so-called democracies in the World. In Brazil we have one of the purest racial democracies in the Western Hemisphere ... It is not preferable not to put this racial problem in terms of future of political democracies of the world, but rather in terms of the philosophy of each country, in its treatment of races ... The Negroes in Brazil do not need any other philosophy to substitute for their own. They ask only that they be left alone in their own surroundings to continue an old tradition of freedom, tolerance and liberty on Brazilian soil. They not need lessons and prospects for the world to come. They already have facts, wonderful facts. They want to be heard, because they have much to teach the "superior" races in this troubled world. (Ramos 1941a:515)
\end{abstract}

Ramos was not alone in his very positive view of the supposedly innate Brazilian attitude of tolerance and acceptance on the part of Negroes of a benign philosophy of race. Gilberto Freyre (1941:513) also contributed to an edited issue of the Journal of Negro Education with a comment about the unpopularity of fascist ideas among the poor and illiterate. Brazil's colonial past and national imagination explained, in Ramos and Freyre's view, the uniqueness of the so-called "Brazilian tradition," as well as its "natural"

committed to drawing Ramos to the meeting of the association, stressed the symbolic and political importance of the Brazilian anthropologist. As Ramos was unable to obtain funding for himself and his wife to travel to Philadelphia, Herskovits presented Ramos's paper on "Acculturation among the Brazilian Negroes" (Melville Herskovits, December 6, 1940, Box 19, Folder 14, NWUA/MHP). Herskovits recommended Ramos, at that time already in Baton Rouge, and Gilberto Freyre, as people who might be advantageous for the Division of Cultural Relations to bring to the United States (Melville Herskovits to Charles Thomson, September 18, 1940, Box 25, NWUA/MHP). It should be noted that Freyre was another frequent and early traveler to the United States. His impressions of the U.S. South were decisive in his depictions of the plantation of the Brazilian northeast. Space limitations do not allow me to discuss in this essay the implications of Freyre's travels and passage through different universities in the United States between the 1920s and 1940s, and their importance in drawing attention to his interpretation of Brazil. 
antipathy toward the importation of models, of the foreign and the unknown. Anti-imperialist feelings fed the national imagination and a supposedly benign colonial experience would surpass its boundaries and be used as a model for other nations. These comments were not made in conjunction with impressions Ramos had of the African-American rural population in Louisiana. However, to some extent, a comparative view informed the very assumptions in his understanding of what he called the "Brazilian Negro." Instead of appearing in the articles he wrote during his stay in Baton Rouge and Evanston, this contrastive tone appeared explicitly in his "letter from the United States" published in Diretrizes. In an interview offered to the journal before his departure, Ramos revealed his plan of studies: to debate the "Brazilian experience ... based on four centuries of wealthy humanism," and explore the Mississippi valley region as a "field" of investigation for comparative studies of the New World Negro. ${ }^{25}$ Despite his plans, there are few indications that he succeeded in his pursuit. In part this was because of the understandable difficulty with communication in Creole, but also possibly because of the segregated nature of the university. In a later article he mentioned that he had made contacts with "gumbo" speakers who maintained African traditions, though he was not able to fully understand their dialects:

\begin{abstract}
All of this seems to pertain to a definitely dead past ... there are, however, some shadows roaming through its margins and I am making a great effort to listen to its gloomy voice ... the old Negro Carey from St. Francisville plantation and others, from old plantations in northern Baton Rouge - from Oakley to Live Oak - tell me in their almost incomprehensible gumbo, the history of migrations which depeopled Mississippi. Persecuted and ill-treated, Negroes lived roaming and looking for better places. I have seen their little houses made of wood, from the mouth of the river with its groups of fishermen, to the little towns of the Louisiana bayous. (Ramos 1940a:50)
\end{abstract}

Ramos prudently never mentioned segregation as a problem, but referred to it through rhetoric that mixed past memories with images of the U.S. South fabricated by books and movies. Rather than dealing with his personal experience of living in a White middle-class segregated university in Baton Rouge, he highlighted his position as a foreigner, a Brazilian (and never Latin American) professor who offered to White students a view of a paradise south of the Rio Grande. Ramos complained about the complete ignorance within intellectual circles of the "people and lands of South America." With students, however, he seemed to be more complacent, perhaps because his position as a kind of "translator" of Brazilian racial philosophy did not

25. He also mentioned plans to contact scholars and carry out research on "social psychology" (citing Frank Alexander's and Smith Ely Jelliffe's studies) concerning childhood, hygiene, and problems of mental illness (Ramos 1940b:30). 
seem to be threatened. In his archive there are many students' letters and final term-papers, most of them suggesting positive impressions of Ramos and the Brazilian situation regarding race. Nevertheless, there is no mention of Baton Rouge, Louisiana State University, the South, or even the country's racial problems. He even complained that Carmen Miranda's popularity in the country had produced distortions in the already confused image of Brazil as a Spanish-language country, and his view of his role in Baton Rouge was that he was a missionary who fulfilled his task: "they recognized that much of their democracy has a lot to learn from ours." 26

Brazilian images, songs, and characters were actually the incidental theme of his ethnographic prose. Inspired by William Cullen Bryant's "Children of Old Man River," he wrote about his feeling of loss in realizing that Mississippi was no longer what North American literature and cinema had portrayed. Later, writing about some features which, in his view, produced the basis for "common denominators" of "American Culture," Ramos suggested that what he had called the backyard of America was part of a larger map which drew together national fragments of the "same human configuration," the Negro presence in the Americas. At the same time, this perception seemed reduced to an attempt to humanize an unknown geography. By seeing it through an already familiar lens, Ramos depicted the Mississippi as an extension of Brazilian landscapes: "its [the river's] presence constitutes one of those common denominators which give a uniform cast to American culture. The Negro slave in the Mississippi Valley is the same Negro as a slave in the valley of the Rio Parahyba in Brazil. The same voice, the same songs, the same physiognomy, the same history" (Ramos 1940a:31). Oil, trains, poverty, and human suffering (metaphorical references used by Ramos to refer to racism and segregation) had changed the river, and by extension, an important symbol of the U.S. South. The Mississippi was a central image moving Ramos to observe the past of the South and draw connections with the Brazilian situation. The contrast, in this case, proved to be more relevant.

It seems unlikely that he completed his planned fieldwork, although his North American colleagues may have encouraged him, and his expertise in Afro-Brazilian studies made it a particularly relevant undertaking. Nonetheless, it is his duties as a translator of Brazilian culture which are most evident in the archival material. In all the lectures he gave at American universities, Ramos stressed the benign character of the Brazilian racial scenario and attributed the shift from racial determinism to a cultural interpretation of race in Brazil to the emergence of the social sciences. Shortly after his return to Brazil, Ramos began to write parts of an essay in which he described Brazilian anthropology as both a tool and a language to combat racial intolerance. In Guerra e rela-

26. "Here, at the university people think that 'Señorita' Miranda is Argentinean" (Ramos 1943b:10; 1942:10). 
ções de raça (War and race relations, 1943), Ramos clearly laid out the basis for his use of travel experiences in a nationalist and disciplinary focus. Rather than offering material for study, as he frequently stressed in his writings, the Brazilian "tradition" or "philosophy" of race - as he often called it - offered multiple tools to deal with problems of analysis regarding race relations. In Ramos's view, this position had its roots and history in the very development of the social sciences in Brazil, and in the early response of Brazilian intellectuals to racial determinism in 1935 (Chor Maio 1998, Stolcke 1998).

In a way, what Ramos and some of his biographers referred to as an experience of transformation of his analytical tools - from the influence of Nina Rodrigues's School to a position strongly marked by his use of the concept of culture - was not necessarily related to his travel experience in the United States but to the role he imagined a Brazilian anthropologist had to assume when working in wider efforts at intellectual cooperation. ${ }^{27}$ Even if Ramos did not exactly challenge the plans some North American institutions and intellectuals had for him, he still used the "knowledge" and "training" he supposedly received during his trip to the United States for his own benefit. While New World countries had features that could permit comparative approaches to Afro-American studies, few were in a position to set up the basis for a wider program of studies. Rather than an applied discipline, anthropology had to be subject to the claims of a "democratic order." Brazil, in Ramos's view, had exceptional conditions for pursuing this position.

His highly nationalist approach to the role of anthropology in producing a scientific interpretation of nationality would be taken into account in two other institutional arrangements related to "problems of race": the founding of the first Brazilian professional association of anthropology, the Brazilian Society of Anthropology and Ethnology, and later, Ramos's position in the Social Science Department at UNESCO, together with his insistence on the choice of Brazil as a "laboratory" for international research on race relations, just before his premature death in $1949 .{ }^{28}$

\section{AN HERDERO DE ABOLENGOS NEGRIBLANCOS}

In 1941, when Rómulo Lachatañéré, a Cuban writer trained as a pharmacist, demonstrated interest in seeking advice from Herskovits and William Bascom, Herskovits referred to Arthur Ramos as someone already recognized for his

27. Even before Ramos's trip to the United States, the acculturation studies by Herskovits, Ralph Linton, and Robert Redfield had an important influence on the reorientation of his publications (Redfield et al. 1936, Herskovits 1937, Ramos 1941b).

28. For an analysis of these experience see Stolcke 1998, Chor Maio 1998, and Barros 2005. 
authority on Afro-Brazilian religion and who might be helpful to Lachatañéré in his plans to study in the United States. Following upon a letter from Lachatañéré in which he thanked Ramos for suggestions and comments on his research plans, they met in the spring of 1941 in New York. Lachatañéré's signature and dedication in his Manual de Santeria, sent to Ramos in 1942, is still preserved in one of the books in Ramos's collection. ${ }^{29}$

Unlike for Arthur Ramos, we have little biographical information on Rómulo Lachatañéré and little significant intellectual production. ${ }^{30}$ Besides a compilation of his books and articles published in Havana in 1992, and other writings published in Cuban and North American journals, of which Lachatañéré seemed to be unaware (as he cited in his application to the Julius Rosenwald Fund by 1942) only fragments were left from his short career as an anthropology student (Lachatañéré 1992). ${ }^{31}$ From 1938, the date of his earliest writings, to his death in an airplane accident on his return from Puerto Rico to New York in 1952, Lachatañéré wrote many articles presenting AfroCuban religions in a creative and innovative way. Since my aim is to produce a comparative overview of his interpretation of the relation between nation and race through his travel experience, rather than a biographical account of his life or a detailed analysis of his writings, the following information is admittedly tentative and incomplete.

Rómulo Lachatañéré was born in Santiago de Cuba in 1909, in a family with a long history of involvement in the War of Independence. His grandfather, a colored leader "from a Haitian family of coffee farmers and former slaveholders," was directly involved in the insurgent movement and figures as one of its more important characters, Flor Crombet. In the early decades of the twentieth century, Oriente was also the important setting of an explicitly racialized political movement led by nonwhite Cubans which had ramifications throughout the island. The mobilization, organized as a political party and led by los Independientes de Color, aimed at confronting racial and social inequalities in jobs, political representation, and at giving access to housing and education during the U.S. occupation. At the same time, its priorities and demands challenged the nationalist atmosphere of the aftermath of the War of Independence by proposing to discuss questions related

29. "Para el Prof. Ramos con admiración" (To Professor Ramos with admiration). Dedication in Spanish in a volume of Lachatañéré's Manual de Santeria in the Division of General Bibliography at the Biblioteca Nacional do Rio de Janeiro.

30. Besides ;Oh, mío yemayá! Cuentos y cantos negros (1938, see Lachatañéré 1992a), Manual de Santeria (Lachatañéré 1942), and articles published in Cuban and U.S. journals (1939, 1943, and 1961), reprinted in 1992a, 1992b, 1992c, 1992d, and 1992e, I located other writings of Lachatañéré published posthumously: 1952, 1953.

31. Rómulo Lachatañéré y Crombet, [1942], “Julius Rosenwald Fund Application,” Julius Rosenwald Collection, Special Collection/Fisk University. 
to law, property rights, citizenship, and political power in the Afro-Cuban population. Lachatañéré spent his first years in a setting that featured the strong influence of Haitian migration and its descendant population, as well as the events that marked the Oriente region as a place of rebellion and racial insurgency. ${ }^{32}$

After his first years of study in Santiago de Cuba, Lachatañéré moved to Manzanillo and Havana where he joined the Faculdad de Medicina y Farmacia at the University of Havana in 1926. As a doctor specialized in pharmacy, he worked in the Institute of Venereal Diseases as a laboratory technician and, as noted in his biographies, was involved both with communist groups and literary avant-garde societies related to the Afrocubanismo movement. ${ }^{33}$ This movement, which involved many aspects of cultural production and political participation in Cuba during the 1920s, drew a heterogeneous group of artists, intellectuals, and political activists engaged in promoting a wider discussion on the very nature of the nationalist project envisaged by José Martí and other nationalist leaders at the turn of the century. The idea of a unified and homogeneous nation, regardless of race, began to be questioned by many prominent figures in a related intellectual mobilization during the 1920s. Afrocubanismo allowed for the integration - however conflictive and involving dissonant positions - of white and nonwhite participation in a set of initiatives concerning national representation. With ambivalent attitudes toward the place of the Afro-Cuban population in the representation and future of the nation, some of its participants were hesitant to adopt an integrationist discourse and conciliatory criticism. A rhetoric inspired by ethnology and folklore studies allowed for the proliferation of different spaces of discussion created to this end. The uses of and emphasis on African and "black motifs" in debates toward radically integrated alternatives to the nation moderated the radicalism of 1912 and events of the early 1930s. The publication of periodicals and performances of poetry, music, and the arts were the main vehicles for the effervescence of Afrocubanismo (Moore 1997, Schwartz 1998, Bronfman 2004). The

32. As Ferrer (1999) has pointed out, there are innumerable sources about the War of Independence period which refer to the contingency of volunteers who originated in Santiago de Cuba and nearby areas, by stressing racial features related to the incapacity of some troops led by negroes and mulattos to perform in a military and civilized "spirit." On Flor Crombet, see Ferrer 1999:80-82 and de Córdova 1939. On the mobilization of the Partido Independiente de Color (PIC) and other struggles for racial equality in the first half of twentieth century see Pérez, Jr. 1986, Helg 1995, Fuente 2001, Bronfman 2004.

33. Rómulo's biographical information is found in Guillén 1962, Instituto de Literatura 1980, Barreal 1992, and Diana Lachatañéré, "Chronologia de la vida de Rómulo Lachatañéré y Crombet" (manuscript, $\mathrm{n} / \mathrm{d}$, courtesy of Diana Lachatañéré). I also thank Angel Augier for sharing his knowledge and recollections of Lachatañeré. For critical readings and reviews on Lachatañéré's writings, see Ortiz 1992, Portuondo 1938, 1945, Sánchez 1987, Castellanos 2002. 
essay and poetry were the main styles chosen by this generation to establish the bases of its utopian project and national pursuits. The interpretations of Cubanidad, a category that received different definitions, acted as multiple configurations of a common national desire for integration. As Alejandro de la Fuente argued, "although some of the writers who followed this 'black craze' portrayed blackness in highly stereotypical terms, others used cultural expressions of perceived African origins to assert Afro-Cubans' seminal contribution to Cubanness and to Cuban culture, emphasizing in the process the mestizo character of the Cuban nation" (de la Fuente 2001:182).

One of the first media for discussion and dissemination of these ideas appeared in the creation of the Society of Cuban Folklore (Sociedad del Folklore Cubano) in 1923 and in the publication of writings of its members in the journal created by the society, the Archivos del Folklore (1924-1930). Along with the avant-garde Revista de Avance (1927-1930), and later, the Estudios Afrocubanos (1937-1940, 1945-1946), they were privileged spaces for publicizing debates concerning literature and intellectual thought from a folklorist and nationalist perspective. In June 1936 the Society of AfroCuban Studies (Sociedad de Estudios Afro-Cubanos) was founded with more pragmatic motives: the "careful study of ... literary phenomena produced in Cuba through the comingling of distinct races." (Sociedad de Estudios Afrocubanos 1937:7). Among its exponents the society brought together figures such as the communist Juan Marinello, Afro-Cuban activists such as Gustavo Urrutia, and liberals such as Don Fernando Ortíz and Israel Castellano, as well diverse artists and intellectuals, including José Luciano Franco, Nicolás Guillén, Herminio Portell Vilá, Miguel Angel Céspedes, and others. Rómulo Lachatañéré was also among its founders and it was in the magazine that he became known as "folklorist."

Fernando Ortiz was doubtless the leading figure of this intellectual movement. Educated as a lawyer and trained under Italian positivist criminology by the turn of the nineteenth century, his major work on the Afro-Cuban population and their religious practices in Havana, Los negros brujos (1906, see Ortiz 1917), had influenced not only Cuban state institutions and policymakers and their projects of social reform, but also intellectuals and their approaches to nation building. Nevertheless, in the late 1930s, Ortiz was recognized because of his connections to the Society of Afro-Cuban Studies and the journal Estudios Afro-Cubanos. It was because of his contact with a younger and eclectic group of intellectuals that his writings began to reflect a modest reorientation. ${ }^{34}$ Besides other political and intellectual reasons out-

34. Since 1936 Ortiz had been publishing fragments of his Contrapunteo in the Revista Bimestre. Among his later works that express this reorientation are Contrapunteo del tabaco y del azucar (1940, see Ortiz 1978), Marti y las razas (1942), El engaño de las razas (1946), and "Los Negros y la transculturación" (1951). 
side the scope of this essay, this reorientation could be situated in the same complex network of U.S. foreign policy regarding Latin American countries and the place of anthropology in its agenda. Once exiled to the United States by Machado's regime during the early 1930s, Ortiz served as interlocutor in transnational dialogues involving North American and Latin American scholars such as Pattee, Herskovits, W.E.B. Du Bois, Ramos, Price-Mars, and Frank Tannenbaum. The Cuban intellectual pursued plans of establishing the basis for an Inter-American Institute of Afro-American Studies in Havana by early $1940 \mathrm{~s} .{ }^{35}$ These contacts with and views on racial integration in Cuba permitted Ortiz to rethink the orientation of his first works, and to redirect and reframe his readings and writings toward what he called etnografia (ethnography). As in Ramos, his understanding of the role of the anthropology as both theoretical and methodological tools to understand "Afro-Cuban culture and folklore" was seemingly merged with a nationalist view on the place of Cuba as an example of racial harmony during times of war. ${ }^{36}$ At any rate, in 1940 Ortiz seemed touched by criticism his work had received from the pen of a young Afro-Cuban scholar.

Lachatañéré's earliest contributions to Estudios Afro-Cubanos drew the attention of participants and readers of the journal because they offered an opportunity to read alternative interpretations of Afro-Cuban religion presented by a young Afro-Cuban scholar who openly challenged Fernando Ortiz's intellectual authority and his negative portrayal of Afro-Cuban religions (Lachatañéré 1939, 1940, 1945-46). ${ }^{37}$ Although he frequently praised Ortiz's books and personal support, Lachatañéré's writings demonstrated a different approach to the Afro-Cuban religious practices than Ortiz depicted them in Los negros brujos (see Ortiz 1917). For Lachatañéré the use of the term brujos (witches) for people and brujeria (witchcraft) to describe their religious practices was inadequate and charged with prejudice. At the very least, he carefully argued, their use resulted from "informants with bad intentions" or who did not know the nature of religious activities of Afro-Cuban origin. For Lachatañéré it was important to understand the processes through which divinities of African origin associated with Catholic saints came to be called "saints" and those who operated with their forces, effects, and beliefs,

35. At the end of his short stay as Latin American scholar in the United States in 1948 under the Department of State Travel Program, Ortiz had ambiguous feelings, mingled with harsh criticism, regarding "Pan-American cooperation." See the letter Fernando Ortiz sent to the cultural attaché of the American Embassy, June 13, 1949, Biblioteca Nacional José Martí (hereafter BNJM) in Havana, Colección Fernando Ortiz. Even before this visit Ortiz had very close relationships with U.S. institutions, agencies, and state representatives who traveled to Cuba.

36. Letter, Ortiz to J. Le Riverend, November 11, 1945, BNJM.

37. Posthumously published together as "Las creencias religiosas de los afro-cubanos y la falsa aplicación del término brujería," in Lachatañéré 1992. See also Gutiérrez 2002. 
santeros. In fact, Lachatañéré was one of the first authors to call attention to the specific dimension and location of this style of syncretism from which the figure of santero was derived. ${ }^{38}$ Although related to Ortiz through his collaboration as co-founder of the journal, Lachatañéré saw the first formulations of Ortiz from a critical and reserved perspective.

Despite this criticism, judging from the correspondence which the two maintained between 1939 and 1949, Lachatañéré and Ortiz remained on friendly terms. Each, however, held a different position, at least apparently sustained through mutual recognition of their diverse, and in some ways complementary, "authorities." Lachatañéré recognized the "authority" of Ortiz in the field, portraying himself as a "follower," and Ortiz, on his part, exalted the importance of the writings and origins of Lachatañéré. Ortiz received Lachatañéré's' first book ; Oh, mío yemanyá! (1938, see Lachatañéré 1992) as a literary oeuvre. Despite "deficiencies and insufficient information," argued Ortiz, the collection of "legends" and their publication in Cuba constituted an important contribution to "Afro-Cuban studies." In the prologue, Ortiz recognizes the importance of an untrained effort, compared to those already made by Lydia Cabrera and Alejo Carpentier in Cuba. The author, points out Ortiz (1992:ix), is the descendant of a Black-White family ("es herdero de abolengos negriblancos"). Although Ortiz had highlighted the French and Haitian influence in Lachatañéré's's "Castellanized" name - originally Lachataignerais - this very particular way of introducing the author and emphasizing aspects of his writings would follow Lachatañéré in other situations.

Finally, although we have insufficient information on Lachatañéré's participation in the Sociedad de Estudios Afro-Cubanos, this experience and political involvement redirected him to an interest that would absorb his attention during the 1940s. Political problems were credited as causes of Lachatañéré's departure from Cuba to New York in 1939. However, we could add to these his interest in studying anthropology and pursuing other interpretations of the treatment of narratives on the practices of santeros. After his attempts to follow a professional career in anthropology in the United States, he was engaged in war efforts, acting as a World War II volunteer and serving in medical units in South Carolina and Africa in 1943-1944. Subsequently Lachatañéré worked as a laboratory technician in New York, studied photography, and joined leftist and cultural activities through the Council of the Arts, Sciences and Professions in New York. By the time of his tragic death he was preparing a photographic exhibition on Puerto Ricans. ${ }^{39}$ A close look at Lachatañéré's writings produced

38. Ortiz replied in "Brujos o santeros," (1939:87) arguing in favor of pioneering his work, since after Nina Rodrigues he was the first to launch himself in a direct observation.

39. Lachatañéré was arrested and spent several months in prison in 1934. See Instituto de Literatura 1980:482. As Diana Lachatañéré noted, "according to my mother, the authorities searched his room and found what they claimed was 'subversive literature (that is, 
in his first years in New York permits us to highlight divergences in the representation of the presence of the Afro-Cuban population created by other Cuban authors of his generation, and also recognize how his understanding of Santeria as a metaphor of nationhood changed along with his own experiences as a traveler in several New York neighborhoods.

\section{FROM LOS JARDINES BOTÁNICOS DE HARLEM}

By early 1940, at the same time that Lachatañéré introduced himself to Melville Herskovits, highlighting his ethnographic experiences in Cuba, Ortiz recognized his former colleague and emphasized his affiliation with the Society of Afro-Cuban Studies in a letter of recommendation sent to his North American colleagues. Reaffirming the position of authority of Ortiz and his training in the "tradition of studies" which he had introduced, Lachatañéré called attention to the "ethnic origins of Afro-Cuban practices" and their consequent process of "amalgamation" in Cuba as complementary areas of pursuit in this research. These two subjects constituted the basis of what appears to be the core of his writings at the time: the study of the nature of the combination of Catholic and African beliefs (creencias) in Cuba. In a twenty-four-page manuscript attributed to Rómulo Lachatañéré included among the papers of Fernando Ortiz at the Instituto de Literatura y Lingüística, his ideas appear in the form of a plan of study. Entitled "Some Suggestions on the Study of Afro-Cubans," the text analyzes aspects of the "Black presence in Cuban culture ... for the study of our ethnology," and reaffirmed the need to consider what Lachatañéré called the "amalgamation":

we could draw the following conclusion. Each African group that manifests itself in Cuba, studied specifically, expresses the sum total of all of the beliefs brought together in a single group, where individual definitive traces manifest themselves that allow for identification. Thus within African beliefs, originating in Cuba, there has also been a process of amalgamation. 40

This preoccupation with the aspects of combination, transformation, and reinterpretation, beyond repeated allusions throughout Lachatañéré's limited correspondence, would show up in his other writings. This suggests the differences that influenced the vision of Cuban intellectuals on what they saw as

against the Machado regime)." Diana Lachatañéré, "Chronologia de la vida de Rómulo Lachatañéré y Crombet”, manuscript. See also Barreal 1992 and Guillén 1962.

40. [Rómulo Lachatañéré], "Algunas sugerencias acerca de los estudios de los afro-cubanos," Carpeta 245 "A," Colección Fernando Ortiz, Instituto de Literatura y Linguística, Academia de Ciencias de Cuba (hereafter CFO/ILL) in Havana. 
part of "Cuban culture" and elements that Herskovits and his students interpreted as representing "African survivals" in the New World. Lachatañéré gave to the idea of "amalgamation" a unique meaning. On the one hand, this meant an emphasis on the "nation," and on the other, a re-elaboration of constructions of "culture" and "race."41 Rather than reproducing what David Scott (1991:263) termed the "verificationist" perspective and its preoccupation with the African origins of cultures and populations descended from slaves in the Americas, Lachatañéré (1992b:194) appeared to be more focused on studying the dialogues produced by these various sectors in Cuba. As a metaphor that seems derived from the field of chemistry, "amalgamation" consisted in the production of a new substance in which the original elements that composed it were no longer visible or recognizable. Different from the culinary metaphor used by Ortiz in which Cuban culture and nation were compared to an ajiaco, a Cuban dish that preserves the different ingredients and their time of cooking, amalgamation laid more emphasis on the formation of nation as a new, united political and cultural entity regardless of its cultural past. ${ }^{42}$

Letters exchanged between Melville Herskovits and Fernando Ortiz suggest that upon his arrival in New York, Lachatañéré began a process of reevaluation of his earlier writings as well as the methods used in his research on santeros, including impressions of his own procedures for collecting material. By sending what was probably the manuscript of Manual de Santeria, he requested specific advice:

In 1937 I wrote a book of tales entitled ;Oh mio Yemanyá! based on myths and legends I collected among the so-called santeros in La Habana and Santiago de Cuba. The book suffered from a weak elaboration of the tales, reduced to mythological aspects ... I have lived among santeros for approximately three years ... and I know many of their superstitions and magical practices ... the aim of this letter is to request suggestions and help ... because I recognize your experience in these studies, which would help me in my work. ${ }^{43}$

Although recognizing the limitations of his knowledge both on Yoruba influences in Cuba and Africa, Herskovits actually replied with comments, suggesting other authorities on such subjects such as Fernando Ortiz. He also enclosed an extensive review of Lachatañéré's manuscript written by his student William Bascom, who highlighted the main problems found in his reading. For Bascom, Lachatañéré's manuscript lacked appropriate methodology, as well as information about places, informants, and bibliographical

41. See also Wirtz 2004 and Palmié 2002.

42. For an exploration of the idea of ajiaco by Fernando Ortiz, see Palmié 1998.

43. Rómulo Lacahatañeré, New York, September 11, 1940, NWUA/MHP. ;Oh mio yemanyá! is dedicated to Panchita Cárdenas, humilde yalocha de la villa de Regla (humble yalocha from the village of Regla). 
references. There were great variations in the rituals and names of deities in Havana and Santiago, which weakened any attempt to compare these sources to information about the Yoruba in Africa. Also, the data concerning what the author alleged to be elements of Yoruba culture and religion in Cuba had no equivalent in Bascom's own material on West Africa. The major problem seemed to consist of differentiating what was collected through Lachatañéré's fieldwork in Cuba from information gathered from literature about the Yoruba in Africa. Bascom considered Lachatañéré's work interesting as an exploration of Cuban culture, but lacking as a study of acculturation, which Bascom thought should be undertaken by someone more familiar with Yoruba culture. Finally, his conclusions were close to other intellectuals' impressions of Lachatañéré's writings during the author's attempts to obtain professional advice and financial support for his research in the United States: he needed "training in method and bibliography." 44 His national view on African aspects of Cuban culture was interpreted both as a result of a lack of professional training and of his position in the field as a kind of "native anthropologist" (Narayan 1993). As Deborah Gordon has pointed out, "in addition to conveying that the fieldworker had a distinctly anthropological experience, an ethnography must also display signs of 'scholarship' that are connected to fieldwork but that do not necessarily signify a unique fieldwork experience. These textual features signify professionalism or the acquisition of academic prestige" (Gordon 1990:147).

Bascom's comments brought Lachatañéré's recognition and acceptance: "I accept your [his] criticism with no reserve ... it will serve to rectify, ordain, and preserve my work in a more concrete way." But Lachatañéré also added that while considering it important, he differed with other interpretations of Afro-Cuban religions. Instead, he preferred to "set the discussion based on my own experiences." 45 Lachatañéré believed that the interaction between

\section{Melville Herskovits, Evanston, February 22, 1941, Box 17, NWUA/MHP.}

45. Melville Herskovits, Evanston, January 9, 1941, enclosed: "Report by William R. Bascom"; R. Lachatañéré, New York, January 26, 1941 (original in Spanish), NWUA/ MHP, courtesy of Diana Lachatañéré. Letters of recommendation from Fernando Ortiz to Franz Boas and Ruth Benedict, Havana, 2/15/1941, Columbia University Archives, courtesy of Diana Lachatañéré. Ortiz also encouraged Rómulo to study "our things ... important to the knowledge of Cuba" (Fernando Ortiz, Havana, 2/15/41, Diana Lachatañéré Collection, courtesy of Diana Lachatañéré). Oddly enough, almost at the same time that Lachatañéré made these comments on the work of Ortiz, Ortiz himself recommended the "young Cuban, Dr. Rómulo Lachatañéré" to Franz Boas, Melville Herskovits, and Ruth Benedict, offering himself as a referee in case Lachatañéré wished apply for a Guggenheim Fellowship. Lachatañéré actually applied for a Guggenheim Fellowship in the same year. The Foundation received from Herskovits positive recommendations regarding Lachatañéré's work. Melville Herskovits, Evanston, April 25, 1941, Box 8, Folder 17, NWUA/MHP. In the same year, after contact with Ruth Benedict, Lachatañéré also 
populations of diverse origins, which made up Cuban culture, represented a poetic language of integration and had little to do with the unique aspects of the different African traditions that existed in Cuba. ${ }^{46}$ In a way, Lachatañéré praised the uniqueness of his own involvement, comparing his encounters with santeros and practitioners, whom he referred to in expressions such as "our friends," not as "fieldwork" but "experience." 47 But Lachatañéré's position combined a double, sometimes ambiguous, perspective in references to his relations with his "friends/informants." In the same letter sent to Ortiz on August 1940 from New York, he describes his activities in the library where, "trying to trace the genealogical tree of my ancestors" he felt the distance that kept him far from his Cuban "others":

I need to return there and love another Black woman so that she gives me details; but I can't do that now; I would like you to help me in this regard, what I want now is to obtain information on the Black ñañigos, could you recommend a publication where I could find what I need, more specifically the existence of this secret society and its origins, what I know of these people is very vague and confusing, I never got involved with these people, I was afraid of them, and now I regret it. ${ }^{48}$

This ambiguity also shows up in the relationship between Lachatañéré and Ortiz. As I mentioned, from the time that Lachatañéré left Cuba, the two corresponded regularly. Lachatañéré was explicit in his reference to Ortiz as the "specialist" on Afro-Cuban studies, and treated him with deference. Although he expanded and reoriented his research interests in the United States, Lachatañéré insisted on staying in contact with Ortiz and other Cuban intellectuals, recognizing in this way the specificities of the "national question." At the end of 1942 Lachatañéré sent a brief description of his research plan, entitled "A Study of Religious Beliefs among Afro-Antillanos (West Indians) in Harlem, New York City." In contrast to his former studies of Cuba, Lachatañéré focused his attention on the city and population with which he had been living since his arrival in the United States. This time, the description of the Spanish-speaking community of Harlem led him to a very skeptical view of the possibility that a population with diverse ethnic and national origins could pass through the experience of "amalgamation" he had emphasized in his works on Cuba. Without explicitly stating that racism

decided to apply to the Rosenwald Fund Fellowship (NWUA/MHP, courtesy of Diana Lachatañéré).

46. For literary aspects of the ¡Oh mio yemanyá!, see Sánchez 1987.

47. For a comparison with the fieldwork experiences of Lydia Cabrera and her understandings about the relationships between ethnographer and practitioners, see Dianteill \& Swearingen 2002 and Rodriguez-Mangual 2004.

48. Romulo Lachatañéré, letter to Fernando Ortiz, August 26, 1940, FOC/BNJM. 
encompassed all causes that kept the "community" insulated in an enclave between "the north end of Central Park to 125th and from Morningside Park to the East River," Lachatañéré suggested that the "segregated environment" promoted isolation. He aimed to focus on both the Negro and Spanish "cultural heritage" of "Antillanos," namely immigrants from the Dominican Republic, Cuba, and Puerto Rico. Once more, religious practices appeared to be a communal arena in which these national and ethnic communities could be perceived as a group. Moreover they provided the basis for a fundamental understanding which would allow for the intervention of "social planning."

\begin{abstract}
The future of the "Hispanos" in Harlem will depend in great measure upon the understanding that is available of their beliefs and practices. At present these are practically unknown outside the group. The proposed study will be a basic contribution to any social planning effort aimed at alleviating the problems of this community ... Publication of my detailed studies would not be immediately advisable on account of possible repercussions upon the community studied. Articles setting forth the conclusions could be easily published in journals interested in ethnic problems, and mimeographed reports with greater detail could be furnished to organizations active or interested in Negro problems. ${ }^{49}$
\end{abstract}

What struck some North American scholars most about Lachatañéré's project was not his actual ideas. His unique proposal attracted attention mainly because of his "color," which Ruth Benedict, Franz Boas, Ortiz, and Herskovits all thought made him particularly well suited to carry out fieldwork on the West Indian population in New York. Benedict mentioned that as a "Cuban Negro" Lachatañéré would have access to his research subjects "to an unusual degree," while Boas was subtler: "he understands his problem well and he knows how to deal with people whom he wants to investigate." Ortiz's support was also directly related to Lachatañéré's identity, and he emphasized the importance of the fellowship to Cuban development in general: "Because he is de color and has spent his adolescence among the descendants of slaves and cult practitioners ... he is well suited ... he is a young, colored Cuban without resources who has had the opportunity to study at our university. A fellowship ... would be a strong acquisition for the culture, and would enable him to join definitively the group of Cuban ethnographers." 50

49. Rómulo Lachatañéré, "A Study of Religious Beliefs among Afro-Antillanos (West Indians) in Harlem, New York," enclosed in Julius Rosenwald Fund Application, [1941], Julius Rosenwald Collection, Special Collection/Fisk University, courtesy of Diana Lachatañéré.

50. Ruth Benedict, New York, January 31, 1942; Franz Boas, New York, 2/5/42; and Fernando Ortiz, Havana, February 18, 1942, Julius Rosenwald Collection, Special Collection/Fisk University, courtesy of Diana Lachatañéré. 
Although, according to Diana Lachatañéré, there is no evidence that Lachatañéré had continued to pursue an academic career after 1943, he transformed part of his reflections on the West Indian population in Harlem into essays in which his experiences as a political activist in Cuba and, mainly, among the Puerto Rican population in Harlem merged. In 1942 Lachatañéré published two articles in New York journals related to his application to the Rosenwald Fund. In "Los Jardines Botánicos de Harlem" (Lachatañéré 1992d) he presented an alternative and comparative view on "Cuba outside national borders." Outlining aspects of the daily life in el barrio latino, he paid attention to the "boticas" or "botanical garden"- a kind of store owned by Antillanos where herbal, medicinal, and religious products were sold. There, and contrary to the legally permitted North American drugstores, dynamic mixtures took place. The pharmacist acted as a faith healer, treating all kinds of physical and spiritual illnesses. But these stores or tiendas also traded manufactured commodities from the Antilles which were rarely found and were even prohibited in the United States. The pharmacist not only knew their properties, but also offered advice on how to obtain better results from some drugs by mixing them as an "alchemist" (Lachatañéré 1992d:393, 395). Lachatañéré, as a trained pharmacist and Santeria connoisseur, referred metaphorically to the Antilles and the Caribbean through the ethnographic depiction of the boticas as a territory of magic encounters and potential combinations. Although Lachatañéré had briefly depicted the social conditions that made the boticas available and popular among the Antillean immigrants, racial tension between the African-American population and Hispanics in New York is suggested as a "problem" that highlighted ethnic identities and religious practices. Although the discrimination that Hispanic and black North Americans experienced placed them in similar social positions, cultural features as well as the particular evolution of the Latino community in New York would produce distinct forms of isolation. ${ }^{51}$

But it is by contrasting these images with those in another essay, "Algunos aspectos del problema negro en Cuba" (Some aspects of Negro problem in Cuba, Lachatañéré 1992c) - that we can perceive his impressions of "Negro problems" in the racial situation of both countries. From New York, the Cuban scenario concerning race seemed to leave him still more confused. Although he stated his discordance with some branches of the Communist Party which, by the late 1930s, took the racial tension of the Southern United States as a model for Cuba, he noticed that since his departure, things had changed: "it is impossible to speak about a 'color line' in the same terms as in the U.S." 52 But

51. Significantly, a Communist Party report on Harlem communities and population echoes this characterization. See, for instance Communist Party of the United States of America, A Political Manual for Harlem (New York City: The Division, 1939); microfilm, Tamiment Library, New York University.

52. In The Negro Quarterly 1(2):145-54, 396-404, 397 (reprint Lachatañéré 1992c). 
discrimination seemed to persist even among nonwhite Cubans. Nationalist appeals were applied to a profoundly unequal society. The ideals of the generation of Martí and the post-Independence War had failed in recent violent events marked by racial antagonism. In some regions, such as Santiago de Cuba and Guantánamo, racial inequalities reinforced antiblack immigration and divisions between "Mulattos" and "Blacks." The strengthening of social conditions that marginalized Blacks throughout the island had created the threefold structure of Cuban society and the division between Blacks, Mulattos, and Whites. Lachatañéré argued that antiblack feelings allowed many Mulattos to adopt "passing" strategies to overcome discrimination. Even among the santeros and their use of Catholic and African religious elements, Lachatañéré perceived differences crossing "racial" and "color lines." The practice of santeros, as well as their relationship with the elites and the state varied between cooptation and political uses of various tendencies..$^{53}$ While Lachatañéré suggested the impropriety of adopting in Cuba sociological models used to interpret race relations in the United States, at the same time, he seemed to agree that the "color line" had benefited different struggles and movements to confront political tyrannies. On the one hand the notion is that competition for resources would worsen racial antagonisms, and on the other, the idea that these conditions provided the basis for a "racial conscience aimed at obtaining political and economic rights." Thus, the recognition of the existence of a "racial problem" in Cuba had to pass through a profound discussion of the models adopted to explain and depict society.

It is impossible to speak of a "color line" in Cuba in the same way that it is approached in the United States; since there is no absolute comparison of these unique conditions, at least with what exists in Puerto Rico. However, there are forms of segregation in all of the important centers of Black population where, due to economic circumstances, Blacks cannot compete with Whites. The "color line" is less effective in urban areas, as in the case of the so-called Black belt of the Oriente province where, due to the fact that the Black population is large and economic resources more abundant, competition with Whites is more favorable. This, however, does not prevent racial prejudice, but simply leads to specific manifestations. (Lachatañéré 1942:39)

According to Lachatañéré, this specificity is due to the reaction of black groups to constant discrimination in large urban areas, such as Havana, Santiago de Cuba, and Guantánamo. Nevertheless, in situations in which the racial balance did not result in a struggle for resources and rights, a process of dislocation and conflicts of a nonracial nature would take place. Lachatañéré emphasizes

53. Wirtz (2004:412) presents an interesting interpretation on the reading of Lachatañéré for the context of Santiago de Cuba. 
this interpretation in his reading of the main events in Cuban political life during the 1930s. In a semi-journalistic account that included remembrances of militancy in the Communist Party, Lachatañéré concluded his analysis with an interpretation of the "racial problem" of Cuba, relegating it exclusively to the political sphere. "Racial integration" appeared in the processes of political struggle for "democratic rights." Although the question only appeared in the conclusion of his text, for Lachatañéré the political sphere was the ideal place for the reconfiguration of economic and unequal forces.

\section{CONCLUSION}

In contrast to Arthur Ramos, Lachatañéré's intellectual production was modest. His treatment of racial issues, reinterpreted from the perspective of his North American experience, had only begun when his intellectual career ended with his death in 1951. The experiences of Ramos and Lachatañéré in the United States, however, are examples of how the confluence of discourse on race and nation, as seen from the perspective of a different cultural experience, subvert any attempt to deal with these categories in an isolated way. While apparently focusing on issues specific to the field of Afro-American studies, both scholars attempted to describe their own nations from outside their political and geographic boundaries and look for definition in contrast. Curiously, the approach chosen by both, in spite of their differing political affiliations and intellectual relationships, appears to fall into the same model. Even if it is impossible to understand the ways in which each interpreted the relation between "nation" and "race" in Brazil and in Cuba as having been the result of a change in perspective caused, above all because before traveling their writings were directed toward other themes, the trip and the comparative perspective present in the writings of each after leaving their countries cannot be overlooked. Still, the so-called "same model" cannot be summarized in a narrative style through which the description by comparison would have the purpose of emphasizing or highlighting difference in a context or situation. While important - and this question should be observed in the texts produced by contemporary North American and Latin American travelers who crossed the borders of their countries seeking to understand the history and life of "Afro-American populations in the Americas" - a comparison, seen only as a "narrative style," obscures the connections and political projects which these authors and members of their intellectual circles had embraced.

By writing about las boticas of Harlem, Lachatañéré envisioned other expressions of religious and cultural affinities among Latin American and Antillean immigrants, where ethnic ties were not based primarily upon national allegiances. Catholic and Afro-Cuban religious practices formed new grounds for ethnic solidarity, and informed, at same time, other mean- 
ings of national identity outside geopolitical borders. Cuban immigrant experiences in a traditionally African-American neighborhood of New York inspired Lachatañéré to highlight similarities in the basis for national formation in the United States and Cuba: the racialized representation of the nation and the national configuration of race. The same seemed to occur in Arthur Ramos's attempts at drawing similarities between the Southern AfricanAmerican population in Louisiana through his experience as a lecturer on "culture and race relations" at a segregated university in Baton Rouge. For Ramos, not only the landscape of the Mississippi, but also its human characters, reminded him of the Parahyba River, which crosscut the poor, underdeveloped, and traditionally former slave plantation area of southeast Brazil. In contrast to the U.S. South however, in Brazil the "nation" had transformed what "race" had produced through history. In his cartography, produced in his chronicles written in Baton Rouge, this process appears as a dehistoricized and "innate tendency" shared by all Brazilians regardless of racial origin.

In a way, their portrait and ethnographic project about Antillean immigrants in Harlem and Southern African-Americans in Baton Rouge can be seen as being close to Mário de Andrade's antigeography metaphor. ${ }^{54}$ Travels and travelers seem to cross more than national boundaries and pursue methodological tools to help them imagine their local and national subjects. As travelers they have to deal, at the same time, with images and mirrors which reflect utopian designs. While both shared the belief that there would be historical and cultural similarities to be identified among these populations in different parts of the Americas, at the same time they also seemed to agree that they should be observed and that they would only be understood within the context of place. In this way, instead of a nation without borders and territories, they imagined the nation and its images that were produced from them as results of mediation, theoretical and political instruments that turned a specific context observable and understandable. With this type of operation, Ramos imagined the sounds and smells of Mississippi and Lachatañéré, in his own way, portrayed a utopian Caribbean in the streets of Harlem. Still, it is important to recognize the trip and resulting narratives as a central element in the construction of a form of authorized knowledge of what is being seen through what was left behind. This because, in spite of the comparison being on the agenda of the various ways of conceiving anthropological knowledge since the late nineteenth century, we have invested little in understanding their influence on theory.

In some ways, the analysis of this type of travel, in which it is impossible to distinguish between tourist, ethnographer, and the participant in a "cultural exchange" between states and institutions, and the complex web of intellectual and political issues involved, suggests a new perspective on the

54. In a way this resembles a wider discussion proposed by Coronil $(1995,1996)$ and what he has termed "non-imperial cartography." 
institutionalization of the field within a different context. What strikes me and inspired me to explore this subject further is the way in which different experiences of displacement - travel as cultural exchange practices on behalf of official political and educational agendas, as well as travel as exile and critical positioning regarding national politics of race - mediated and informed a complex transnational dialogue between scholars and students in the field of Afro-American Studies in Latin America.

\section{REFERENCES}

ANDRAde, MÁRIO DE, 1976. O turista aprendiz. São Paulo: Duas Cidades.

ARAÚJO, RICARDO BENZAQUEN, 1994. Guerra e paz: Casa-grande \& senzala e a obra de Gilberto Freyre nos anos 30. Rio de Janeiro: Editora 34.

ASAD, TALAD, 1973. Anthropology and the Colonial Encounter. New York: Humanities.

BARREAL, ISAAC, 1992. Prologo. In Rómulo Lachatañéré, El Sistema Religioso de los Afrocubanos. Havana: Editorial de Ciencias Sociales, pp. vii-xxiv.

Barros, L.O.C., 2005. Arthur Ramos e as dinâmicas sociais de seu tempo. Maceió: Editora da Universidade Federal de Alagoas. [Orig. 2000.]

BORGES, DAIN, 1993. "Puffy, Ugly, Slothful and Inert": Degeneration in Brazil Social Thought, 1880-1940. Journal of Latin American Studies 25:235-56.

Borneman, JoHn, 1995. American Anthropology as Foreign Policy. American Anthropologist 97:663-72.

Bronfman, Alejandra, 2004. Measures of Equality: Social Science, Citizenship, and Race in Cuba 1902-1940. Chapel Hill: University of North Carolina Press.

CARDOSO DE OliveIRA, ROBERTO, 1988. Por uma etnografia das antropologias periférica. In Roberto Cardoso de Oliveira, Sobre o pensamento antropológico. Rio de Janeiro/ Brasília: Tempo Brasileiro/CNPq, pp. 143-59.

CAStellanos, JoRge, 2002. Pioneros de la etnografia afrocubana: Fernando Ortiz, Rómulo Lachatañeré, Lydia Cabrera. Miami: Ediciones Universal.

CHOR MAIO, MARCOS, 1998. O Brasil no concerto das nações: A luta contra o racismo nos primórdios da Unesco. História, Ciências, Saúde - Manguinho 5:375-413.

Clifford, JAMES, 1988. The Predicament of Culture: Twentieth-Century Ethnography, Literature, and Art. Cambridge MA: Harvard University Press.

—, 1989. Notes on Theory and Travel. Inscriptions 5:177-87.

—, 1992. Travelling Cultures. In Laurence Grossberg, Cary Nelson \& Paula Treichler (eds.), Cultural Studies. New York: Routledge, pp. 96-112. 
—, 1997a. Spatial Practices: Fieldwork, Travel, and the Disciplining of Anthropology. In Akhil Gupta \& James Ferguson (eds.), Anthropological Locations: Boundaries and Grounds of a Field Science. Berkeley: University of California Press, pp. 185-222.

—, 1997b. Routes: Travel and Translation in the Late Twentieth Century. Cambridge MA: Harvard University Press.

CóRdOVA, FEDERICO DE, 1939. Flor Crombet (El sucre cubano). Havana: Cultural.

CORONIL, FernANDO, 1995. Transculturation and Politics of Theory: Countering the Center, Cuban Counterpoint. In Fernando Ortiz, Cuban Counterpoint Tobacco and Sugar: Counterpoint of Tobacco and Sugar. Durham NC: Duke University Press, pp. ix-lvi.

—, 1996. Beyond Occidentalism: Toward Non-Imperial Geo-Historical Categories. Cultural Anthropology 11:51-87.

CORREA, MARIZA, 1998. As ilusões da liberdade: Nina Rodrigues e a antropologia no Brasil. Bragança Paulista: Usf.

CUNHA, OLÍVIA M.G., 1999. Sua alma em sua palma: Identificando a "raça" e inventando a nação. In Dulce Pandolfi (ed.), Repensando o estado novo. Rio de Janeiro: Editora Fundação Getúlio Vargas, pp. 257-88.

—, 2002. Intençao e gesto: Pessoa, cor e a produçao cotidiana de (in) diferença no Rio de Janeiro, 1927-1942. Rio de Janeiro: Arquivo Nacional.

—, 2004. Minha Adorável Lavadeira: Uma antropologia mínima em torno do Edifício Tupi. Anais da Biblioteca Nacional do Rio de Janeiro 1999:59-108.

Di LeONARDO, MicAela, 2000. Exotics at Home: Anthropologies, Others, and American Modernity. Chicago: University of Chicago Press.

DiANTEILL, ERWAN \& SWEARINGEN, MARTHA, 2002. From Hierography to Ethnography and Back: Lydia Cabrera's Texts and the Written Tradition in Afro-Cuban Religions. Journal of American Folklore 116(461):273-92.

DiAs DUARTE, LuIS FERNANDO, 1997. Dois regimes históricos das relações da antropologia com a psicanálise no Brasil: Um estudo da regulação moral da Pessoa. Paper presented at the seminar "Estado, Sociedade e Classificações Sociais," Rio de Janeiro, Brazil.

—, 2000. Anthropologie, psychanalyse et "civilisation" du Brésil dans l'entre-deuxguerres. Revue de Synthèse 121(3-4): 325-44.

ESPINOSA, J. MANUEL, 1976. Inter-American Beginnings of U.S. Cultural Diplomacy, 1936-1948. Washington DC: U.S. Department of State.

FAHIM, HuSSEIN (ed.), 1982. Indigenous Anthropology in Non-Western Countries. Durham NC: Carolina Academic Press.

FARDON, RICHARD (ed.), 1990. Localizing Strategies: The Regionalizing of Ethnographic Account. Washington DC: Smithsonian Institution Press. 


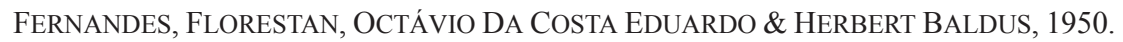
Arthur Ramos 1903-1949. Revista do Museu Paulista 4:439-59.

FERRER, ADA, 1999. Insurgent Cuba: Race, Nation, and Revolution, 1868-1898. Chapel Hill: University of North Carolina Press.

FREYRE, GILBERTO, 1941. Brazil and the International Crisis. Journal of Negro Education 10(3):510-14.

_, 1946. The Masters and the Slaves. New York: A. Knopp. [Orig. 1933.]

Fuente, AleJANDRO DE LA, 2001. A Nation for All: Race, Inequality, and Politics in Twentieth-Century Cuba. Chapel Hill: University of North Carolina Press.

Goldman, MArcio \& Federico NeIBurg, 1998. Anthropology and Politics in Studies of National Character. Cultural Anthropology 13:56-81.

—, 2004. Minha Adorável Lavadeira: Uma etnografia mínima em torno do Edifício Tupi. Anais da Biblioteca Nacional do Rio de Janeiro 1999:59-108.

GORDON, D.A., 1990. The Politics of Ethnographic Authority: Race and Writing in the Ethnography of Margaret Mead and Zora Neale Hurston. In Marc Manganaro (ed.), Modernist Anthropology: From Fieldwork to Text. Princeton NJ: Princeton University Press, pp. 145-62.

GUICHARNAUD-TOLLIS, MiCHÈLE, 1982. Sur quelques aspects du négrisme cubain dans la Revista de Avance (1927-1929). In Actes du colloque international (sur) les années trente à Cuba. Paris : L'Harmattan, pp. 255-76.

GUILLÉN, NiCOLÁS, 1962. Romulo Lachatañéré. In Nicolás Guillén (ed.), Prosa de prisa. Las Villas, Cuba: Universidad Central de Las Villas, pp. 19-73.

GuPTA, AKHIL \& JAMES Ferguson, 1997. Discipline and Practice: "The Field" as Site, Method, and Location in Anthropology. In Akhil Gupta \& James Ferguson (eds.), Anthropological Locations: Boundaries and Grounds of a Field Science. Berkeley: University of California Press, pp. 1-46.

GUTIÉRReZ, MARIElA A., 2002. Réplica de Rómulo Lachatañeré a Fernando Ortiz. Encuentro de la Cultura Cubana 24:267-73.

Helg, Aline, 1995. Our Rightful Share: The Afro-Cuban Struggle for Equality, 18861912. Chapel Hill: University of North Carolina Press.

HersKovits, Melville J., 1937. The Significance of the Study of Acculturation for Anthropology. American Anthropologist 39:635-43.

—, 1958. The Myth of the Negro Past. Boston: Beacon Press.

Hulme, Peter \& Youngs, Tim (eds.), 2002. The Cambridge Companion to Travel Writing. Cambridge: Cambridge University Press. 
INSTITUTO DE LITERATURA, 1980. Lachatanere, Romulo. In Instituto de Literatura y Linguística de la Academia de Ciencias de Cuba (eds.), Diccionario de la literatura cubana. Havana: Editorial Letras Cubanas, pp. 481-83.

KUTZINSKI, VERA M., 1993. Sugar's Secrets: Race and Erotics of Cuban Nationalism. Charlottesville: University of Virginia Press.

LACHATAÑÉRÉ, RÓMULO, 1939. El sistema religioso de los lucumís y otras influências en Cuba: $1^{\text {a }}$ parte. Estudios Afro-Cubanos 3(1-4):28-84.

—, 1940. El sistema religioso de los lucumís y otras influências en Cuba: $2^{\mathrm{a}}$ parte. Estudios Afro-Cubanos 4(1-4):27-38.

—, 1945-46. El sistema religioso de los lucumís y otras influências en Cuba: $3^{\mathrm{a}}$ parte. Estudios Afro-Cubanos 5:191-216.

—, 1952. Oya. Ultima Hora 12:6, 49.

—, 1953. Rasgos Bantu en la Santería. In IFAN, Les Afro-Américains. Dakar: Institut Français D'Afrique Noire, pp. 181-84.

1992a. ¡Oh, mío yemanyá! Cuentos y cantos negros. Manzanillo, Cuba: Editorial El Arte. [Orig. 1938.]

-, 1992c. Algunos aspectos del problema negro en Cuba. In Rómulo Lachatañeré, El sistema religioso de los Afrocubanos. Havana: Editorial de Ciencias Sociales, pp. 396404. [Orig. 1942.]

—, 1992e. Los jardines botánicos de Harlem. In Rómulo Lachatañéré, El sistema religioso de los Afrocubanos. Havana: Editorial de Ciencias Sociales, pp. 393-95. [Orig. 1942.]

LenHaro, AlCIR, 1991. Sacralização da política. Campinas: Papirus. [Orig. 1986.]

MARCuS, GeOrge E., 1991. A Broad(er) Side to the Canon: Being a Partial Account of a Year of Travel among Textual Communities in the Realm of Humanities Centers and Including a Collection of Artificial Curiosities. Cultural Anthropology 6:385-405.

MASIELlO, FRANCINE, 1993. Rethinking Neocolonial Esthetics: Literature, Politics, and Intellectual Community in Cuba's Revista de Avance. Latin America Research Review 28(2):33-62.

Mead, Margaret, 1979. The Use of Anthropology in World War II and After. In Walter Goldschmidt (ed.), The Uses of Anthropology. Washington DC: The American Anthropological Association, pp. 145-57.

MINTZ, SIDNEY W., 1964. Melville Herskovits and Caribbean Studies: A Retrospective Tribute. Caribbean Studies 2(4):42-51.

—, 1977. North American Anthropological Contributions to Caribbean Studies. Boletin de Estudios Latinoamericanos 22:68-90.

-, 1998. The Localization of Anthropological Practice: From Area Studies to Transnationalism. Critique of Anthropology 18(2):117-33. 
MOORE, ROBIN D., 1997. Nationalizing Blackness: Afrocubanismo and Artistic Revolution in Havana, 1920-40. Pittsburgh PA: University of Pittsburg Press.

NARAYAN, KIRIN, 1993. How Native Is a "Native" Anthropologist? American Anthropologist 95(3):671-86.

NEEDELL, JefFrey D., 1995. Identity, Race, Gender and Modernity in the Origins of Gilberto Freyre's Oeuvre. American Historical Review 100:51-77.

ORTIZ, FERNANDO, 1917. Los negros brujos (Apuntes para un estudio de etnologia criminal). Madrid: Editorial America. [Orig. 1906.]

—, 1939. Brujos o santeros. Estudios Afro-Cubanos 3(1-4):85-90.

—, 1942. Marti y las razas. Havana: Molina.

—, 1946. El engaño de las razas. Havana: Editorial Paginas.

—, 1951. Los Negros y la transculturacion. La Nueva Democracia 31:26-8, 138-41.

—, 1978. Contrapunteo del tabaco y del azucar. Caracas: Ayacucho. [Orig. 1940.]

—, 1992. Predisposición al lector. In Rómulo Lachatanéré (ed.), ¡Oh mio yemanjá! Havana: Editorial de Ciencias Sociales, pp. ix-xviii. [Orig. 1938.]

PALMiÉ, StePHAN, 1998. Fernando Ortiz and the Cooking of History. IberoAmerikanisches Archiv 24(3-4):353-74.

-, 2002. Wizards \& Scientists: Explorations in Afro-Cuban Modernity and Tradition. Durham NC: Duke University Press.

PeIRANO, MARIZA G.S., 1998. When Anthropology Is at Home: The Different Contexts of a Single Discipline. Annual Review of Anthropology 27:105-28.

PÉREZ, JR, LOUIS A., 1986. Politics, Peasants, and People of Color: The 1912 "Race War" in Cuba Reconsidered. Hispanic American Historical Review 66:509-39.

PIKE, FrederiCK B., 1995. FDR's Good Neighbor Policy: Sixty Years of Generally Gentle Chaos. Austin: University of Texas Press.

PORTUONDO, J.A., 1938. Reseña. Revista de La Universidad de la Habana 19:177-78.

—, 1945. Manual de Santeria. Estudios Afro-Cubanos 1/2:115.

PRATT, MARY LOUISE, 1986. Fieldwork in Common Places. In James Clifford \& George Marcus (eds.), Writing Culture: The Poetics and Politics of Ethnography. Berkeley: University of California Press, pp. 27-50.

—, 1992. Imperial Eyes: Travel Writing and Transculturation. New York: Routledge.

PRICE, RICHARD \& SALly PRICE, 2003. The Roots of Roots or, How Afro-American Anthropology Got Its Start. Chicago: Prickly Paradigm Press.

RAMOS, ARTHUR, 1928. A sordície nos alienados: Ensaios de uma psico-patologia da imundice. Bahia, Brazil: Livraria e Typ. do Comércio. 
—, 1931. Estudos de psicanálise. Bahia, Brazil: Casa Editora Livraria Científica.

—, 1932. Notas de etnologia: Separata de Bahia Médica. Salvadore, Brazil: Secção Graphica da Escola de Aprendices Artífices.

—, 1933a. Freud, Adler, Jung: Ensaios de psicanálise ortodoxa e herética. Rio de Janeiro: Editora Guanabara.

—, 1933b. Psiquiatria e psicanálise. Rio de Janeiro: Cia. Editora Nacional.

—, 1934. O Negro Brasileiro: Etnografia religiosa e psicanálise. Rio de Janeiro: Civilização Brasileira.

—, 1935. O folk-lore negro do Brasil. Rio de Janeiro: Civilização Brasileira.

—, 1937. Loucura e crime: Questões de psychiatria, medicina forense e psychologia social. Porto Alegre, Brazil: Globo Editora.

-, 1939. O Negro nos Estados-Unidos: Brasil-Estados-Unidos: Fatores de amizade entre duas grandes pátrias americanas. Rio de Janeiro: Diário de Notícias, pp. 323-26.

—, 1940a. Carta dos Estados Unidos: Old Man River. Diretrizes 31:49.

—, 1940b. Um sábio brasileiro nas universidades americanas. Diretrizes 28:29-30.

—, 1940c. Os contatos de raça no Brasil. Diretrizes 29:38.

—, 1941a. The Negro in Brazil. Journal of Negro Education 10(3):515-23.

-, 1941b. Acculturation among the Brazilian Negroes. The Journal of Negro History 26:244-50.

—, 1941c. The Scientific Basis of Pan Americanism. The Inter-American Quarterly 3:2835.

—, 1942. Carta dos Estados Unidos: América portuguesa. Diretrizes 40:10.

—, 1943a. Guerra e relações de raça. Rio de Janeiro: Casa do Estudante do Brasil.

—, 1949. The Question of Races and the Democratic World. International Social Science Bulletin 1(3-4):9-14.

REDFIELD, ROBERT, et al., 1936. Memorandum for the Study of Acculturation. American Anthropologist 38:149-52.

Rodriguez-MAngual, EdNA M., 2004. Lydia Cabrera and the Construction of an Afro-Cuban Cultural Identity. Chapel Hill: University of North Carolina Press.

SÁNCHEZ, S., 1987. Poesia, realidad y mito en ;Oh mio yemanyá! Del Caribe 7:32-45.

SCHWARTZ, Rosalie, 1998. Cuba's Roaring Twenties: Race Consciousness and the Column "Ideales de una Raza." In Digna Castañeda Fuertes \& Lisa Brock (eds.), Between Race and Empire: African-Americans and Cubans before the Cuban Revolution. Philadelphia PA: Temple University Press, pp. 104-19. 
SCOTT, DAVID, 1989. Locating the Anthropological Subject: Postcolonial Anthropologist in Other Places. Inscription 5:75-85.

—, 1991. That Event, This Memory: Notes on the Anthropology of African Diasporas in the New World. Diasporas 1:261-84.

SCOTT, REBECCA J., 1995. Cuba: Questions sociales, raciales et politiques d'une transition à l'autre. Bulletin d'Amerique Latine 17:3-17.

SlOCUM, KARLA \& DEBORAH A. THOMAS, 2003. Rethinking Global and Area Studies: Insights from Caribbeanist Anthropology. American Anthropologist 105(3):87-117.

Sociedad de Estudios Afrocubanos, 1937. Estatuto de la Sociedad de Estudios Afrocubanos. Estudios Afro-Cubanos 1:7-8.

SOUZA CARNEIRO, EDISON DE, 1951. Arthur Ramos: Brazilian Anthropologist (19031949). Phylon 12:73-81.

StEPAN, NANCY LEYS, 1991."The Hour of Eugenics": Race, Gender, and Nation in Latin America. Ithaca NY: Cornell University Press.

StOcKING, JR., GeORGE W., 1968. Lamarckianism in American Social Science, 18901915. In George W. Stocking, Jr., Race, Culture, and Evolution: Essays in the History of Anthropology. New York: The Free Press.

—, 1992. Ideas and Institutions in American Anthropology: Thoughts toward a History of the Interwar Period. In George W. Stocking, Jr. (ed.), The Ethnographer's Magic and Other Essays in the History of Anthropology. Madison: University of Wisconsin Press, pp. 114-76.

StOLCKE, VerENA, 1998. Brazil: A Nation through the Looking Glass of "Race." Revista de Cultura Brasileira 1:51-68.

ThOMAS, NiCHOLAS, 1994. Colonialism's Culture: Anthropology, Travel, and Government. London: Polity Press.

Trouillot, Michel-RolPh, 1992. The Caribbean Region: An Open Frontier in Anthropological Theory. Annual Review of Anthropology 21:19-42.

—, 1998. Culture on the Edges: Creolization in the Plantation Context. Plantation Society in the Americas 5:8-28.

Ventura, RoBerto, 1991. Estilo Tropical. São Paulo: Cia. das Letras.

WAGNER, ROY, 1981. The Invention of Culture. Chicago: University of Chicago Press. [Orig. 1975.]

WIRTZ, KRISTINA, 2004. Santeria in Cuban National Consciousness: A Religious Case of the "Doble Moral." Journal of Latin American Anthropology 9:409-38.

WOLF, ERIC, 1974. American Anthropologists and American Power. In Dell Hymes (ed.), Reinventing Anthropology. New York: Vintage Press. 
Yelvington, KeVIn A., 2006. Afro-Atlantic Dialogues: Anthropology in the Diaspora. Santa Fe NM: School of American Research Press.

OLIVIA M.G. CUNHA

Graduate Program in Social Anthropology

Museu National

Federal University of Rio de Janeiro

RJ Brazil, 222 U5 120

<olivia.cunha@uol.com.br> 